\title{
EFFECTIVE WAYS OF CONTENT CREATION IN DISSEMINATING KNOWLEDGE FROM HEALTH AND SAFETY AREA
}

doi: $\quad 10.2478 /$ czoto-2019-0113

Date of submission of the article to the Editor: $02 / 11 / 2018$

Date of acceptance of the article by the Editor: 18/12/2018

Adam Sokolowski ${ }^{1}$ - orcid id: 0000-0003-1592-5404

Maja Rosi ${ }^{2}$ - orcid id: 0000-0003-4633-8237

${ }^{1}$ Czestochowa University of Technology, Poland, adam.sokolowski@wz.pcz.pl

${ }^{2}$ Faculty of Logistics University of Maribor, Slovenia

Abstract: In the era of a digital transformation of the manner of presenting and distributing content determined by activeness of Internet users, there is a necessity to identify optimum content creation. This aspect is analysed both in the dimension of information as well as marketing strategies. An important element then is to determine both technological as well as behavioural reasons that influence the form of the disseminated information. The paper will present marketing formats of content creation in the processes of disseminating knowledge on health and safety. In this light the Author will also analyse the effectiveness of particular types of content. Classification and characteristics of content will be presented in it as well. The research will be supported by selected tools of internet analytics so as to identify the types of content transfer carriers and the scale of their impact (such as, for example, Google Trends, Google Planner, Ubersuggest, Buzzsumo, Brand24 itp). The presentation will also include expert industry reports that indicate the extent to which in a general grasp the presented creations are applied to formulate interdependencies of applying the identified contents in the scope of the issues related to health and safety. Identifying potential division lines within the content category will allow to formulate a profiled methodology of their application within this specialist area.

Keywords: content, content marketing, marketing strategies, content creation

\section{INTRODUCTION}

Digital transformation concerns various functioning areas of modern enterprises. Its range includes closer and further organization's environment. Digital transformations condition the Internet users' activities and influence their expectations in relation to information being popularized in a virtual environment. Entrepreneurs in order to ensure a close relationship with a potential recipient must make the right choices of distribution channels and forms of content creation. This aspect concerns marketing campaigns, communication processes as well as strengthening social awareness in the field of selected problem areas (the range of educational activities) (Kotler and Amstrong, 2017). In this light, the presented scientific considerations present a 
problem related to the ways of popularizing knowledge in the field of health and safety standards with the use of electronic content published on the Internet. The analysis focused on various formats of content creation, which are used in popular digital marketing strategies, namely content marketing and native advertising. The specificity of native advertising and content marketing is in fact a neutral, non-invasive nature of information transfer (Sokołowski and Wrzalik, 2016). The diverse content formats used by these strategies are characterized by the presence of the following features:

- useful knowledge, included in the guidebooks, educational message

- expert resonance of posted information, which an entrepreneur may identify with performing as a domain expert;

- branch-specific specialist information that can engage variety of audiences;

All these elements are characterized by the degree of integration with the surrounding (environment) where this type of advertising content will be published. The content should ideally follow the websites' specifics to create a unified whole. (Lowell, 2017).

The process is carried out in a multi-level manner through a well-defined postal style, layout in this format and the appropriate selection of material themes in terms of identifying the interest and needs of targeted users (Campbell and Marks 2015).

The popularity of using native advertising is evidenced by research conducted by Interactions Europe and IR Center, which indicate that in Poland this form of marketing is already used by $67 \%$ of media agencies and $65 \%$ of marketers. $79 \%$ of publishers offer various native forms. (Reklama natywna, 2015)

\section{DETERMINANTS OF APPLYING DIVERSIFIED CONTENT FORMATS}

An important factor affecting the shape, nature and form of the expected digital content in the Internet are the transformations of users' behaviors, which are conditioned by the following phenomena (behavioral factors) (Sokołowski and Wrzalik, 2017): decreasing attention span (attention span), the set of impressions experienced by the user when using an interactive product (UX - User Experience) a way of browsing (scrolling), selective attention and associated banner blindness (baners blinder).

The phenomenon called the attention span is one of the determinants shaping the format of network messages and the need to use attractive content creations. This range determines the amount of time spent on performing a single task without losing concentration. Studies conducted by Microsoft prove that the attention span is decreasing year by year (Microsoft Attention Spans ..., 2015). The decreasing ability of network users to concentrate is one of the reasons for the decline in the effectiveness of marketing campaigns based on graphic ads. Extending the page loading process with graphic advertisements has a negative impact on users' engagement and thus reduces the conversion rate, increasing the bounce rate (bounce rate). As a result, it causes the resignation and abandonment of the content related to advertising, but also determines the negative emotional states associated with the brand.

The way content is viewed is also significantly influenced by the usability. Meaning in this case are the criteria such as content visualization, readability, optimization in terms of the editorial format, etc. (here the principles arising from the paradigms are important: User experience - UX). Another case indicating that the banner message (graphic ad) is ignored by the network users and does not fulfill the assumed 
communication function is a phenomenon called banner blindness. It is conditioned by the method of searching for information on the web (Benaway and Lane, 1998). In this case two different algorithms have been identified: a clearly defined goal and focusing only on it or viewing websites sequentially (Pagendarm and Schaumburg, 2008).

Another factor in the group of behavioral factors is the identification of recipients' content viewing. An example here is scrolling (the method of viewing information posted on pages), which affects the rapid omission of the advertising message. Users visit websites focusing on one designated goal. We can note here the low value of the metric which is the duration of stay on the site and to indicate a sensitive place that would engage viewer attention (Fessenden, 2018).

Additional elements influencing the necessity to use new forms of presenting content that are an effective alternative to traditional media are technological changes implemented in information search algorithms. This is about the evolution of Google Inc. search algorithms. (Panda, Pingwin and Koliber algorithms that can be classified as technological factors) (Stricchiola and Spencer, 2016). Systematic updates of exploration data mechanisms in the network have been established in the field of qualitative verification of Internet resources.

Based on the analysis of the research results carried out by AdMetrics, it is possible to point out the large scale and dynamics of the traditional graphic advertisement (banners) on the target environment (Reklama w internecine, 2017). Their analysis shows that there is up to 1.7 thousand of advertising banners views per one network user per month. However, the invasive communication becomes an ignored impact by network users and is deliberately limited by the use of blocking programs. An example can be Poland, which is located in the world leader where such solutions are widely used. The "Ad blocking in the Internet" report shows that $46 \%$ of invasive advertising message (graphic ad) in our country is blocked using Adblock (Ad blocking in the Internet 2017).This fact is also an important determinant of specifying new communication formats that would effectively affect the network user.

\section{CONTENT CREATION FORMATS USED IN MARKETING AND INFORMATION}

An important element of the analysis was the identification of content creations that are used in marketing strategies, including those indicated in these considerations, ie: native advertising and content marketing. For this purpose, based on the literature case study, an attempt was made to create an aggregated set of content creation formats. A wide spectrum of examples is indicated here, taking into account the key types of content in the light of which their characteristics have been defined.

In the first place, reference was made to internet blogs, which are a popular form of content distribution in the Internet. According to Forbes, business websites linked to blogs have 97\% more incoming links than websites without this blog content format (Target Your Customers ... 2018). Connected to the company's website, they can be a representative compendium of knowledge that the company shares with its clients. The advantage of blog entries is their synthetic and concise message.

The second indicated format are the articles. Their content has an expert resonance. An article created for the needs of the Internet should meet the requirements of a press publication. These expert content is important because: they create the image of the company as a leader in the industry, engage experts who have a strong influence on decisions taken in enterprises, build and strengthen the trust of potential customers. This is confirmed by research carried out by Nielsen. They show that $85 \%$ 
of consumers are looking for materials and expert articles in purchasing processes (Henshaw).

Analogous in term of supporting an expert image creation are so-called White papers. They constitute reports through which the company wants to convince potential customers that a given product or their group meets consumer expectations. Therefore, the White papers are, to be an electronic document that shows step by step why it is worth using the company's service. Currently, as much as $65 \%$ of companies use this form in their content marketing strategy. This format has a specific structure. It begins with an introduction to the discussed issue then the challenge and proposals for its solution are presented. An important part of the report are examples from the company's experience (case study). This element creates the image of an expert and trust in the brand. The report should end with general conclusions. White papers are use by $71 \%$ marketers in the $\mathrm{B} 2 \mathrm{~B}$ channel and $35 \%$ in the $\mathrm{B} 2 \mathrm{C}$ channel B2C (B2B Content Marketing 2018).

Case study resembles a White paper in its formula. They are distinguished by the adoption of information analysis from the client's perspective. While the white card discusses the use of the product, the case study illustrates what effect this product has given, on the example of a specific customer (DeMers, 2018). A properly constructed case study should have an accessible reliable message, reference to utilitarian examples, and contain quantitative information in addition to qualitative data. Case studies are used by $73 \%$ marketers in the B2B channel and by $30 \%$ in the B2C channel (B2B Content Marketing 2018).

Another element of the content format are newsletters. These are cyclically sent emails that contain advertising content that is personalized in terms of recipients. They are characterized by the following advantages: the content of the message is closely matched to the recipient, it requires the user's declaration to receive advertising messages. These attributes strengthen customer relationships with the company. In the case of newsletters, there is a downward trend in the use of this form of communication in marketing strategies. In 2017, newsletter and marketing e-mails were allocated in Poland by $14 \%$ less funds than in 2016 (Raport strategiczny Internet, 2018), and in the first half of 2018, the expenses on this form of advertising decreased by another $20 \%$ in annual terms (IAB Polska/PwC AdEx 2018). Most emails are viewed from NGOs $(25.18 \%$ open rate), public sector $(22.61 \%)$ and cultural institutions (21.18\%) (Gajoch -Bielecka and Sala, 2018).

The format with an expanded information volume is an e-book. It is the creation of content that enables deep and essential presentation of any issue. The structure of this electronic document is similar to the layout of the book (Shiratuddin et al., 2003). It is divided into chapters, grouped in a table of contents which enable navigation in the publication. The key goal of an e-book is to draw the attention of potential clients to the discussed topic. An important aspect of this type of format is its role in raising the recipient's awareness of specialist issues as well. E-books are used in content marketing by $35 \%$ of marketers in the B2C channel, but as many as $71 \%$ of marketers use them in the B2B channel (B2B Content Marketing 2018).

The visual group of content formats are infographics and video materials. Infographics are a combination of short and useful content (usually numerical data) presented in graphical form (Conner 2017).

They gain their popularity due to the possibility of presenting specialist problem areas in a friendly and comprehensible way (eg medical subject (lit IN) . The advantage of 
the infographics is their direct distribution through social media. This graphical objects are visible directly in the profiles in the main streams. They can also be a structural part of the content creations mentioned in the section. Through the infographics the companies educate clients, show how to perform an activity, present data, set together and compare it (Mochd et al., 2014). No wonder why the infographics are used $59 \%$ by marketers in content marketing in B2C channel and $65 \%$ in B2B channel (B2B Content Marketing, 2018).

Video materials are becoming more and more used in the areas of e-marketing. These are content visualized in the form of film materials of various lengths. As part of video materials, you can propagate diverse specialist information by specifying the message in any form. These can be short educational materials (video tutorials), instructional programs, product presentations, reference materials (testimonials), webinars, VoD materials, etc. . (Sharon et al., 20018). Also their form can be very diverse, from animation to real-time sharing (VoD). The specificity of this type of information propagation is the ability to directly distribute them on social media and dedicated services youtube, vimeo and mobile technologies. The key feature of video materials determining the effectiveness of impact on the recipient is the presence of an emotional message, which in marketing activities can be a guarantor of interaction and increased activity of Internet users. The increase in the popularity of video materials is confirmed in the AdEx survey, as well as in the Forbes ranking of the 10 most-watched YouTube channels (7th December 2017), which recorded an 80percent increase over the previous year, reaching 127 million dollars income. Marketing agencies permanently increase investments into digital video advertising. Over the years 2016-2018, an increase in investment by $83 \%$ was noted (Video Ad Spend Study 2018).

An important aspect of the considerations was the answer to the question how to specify the effectiveness of the content impact prepared as a part of the marketing campaigns and information materials. Based on the literature case study and the experience of active cooperation within the Content Marketing and Native Advertising working group at IAB Poland, a supposition was formulated that the effectiveness indicators may be the website viewing, incoming links, popularity of expert articles, blog entries, e-book downloads, blog comments, number of links to content on social networking etc. in the number of incoming links.

\section{STAGES OF ANALYZING THE EFFECTIVENESS OF CONTENT CREATION FORMATS}

In order to determine the effectiveness of the content creation formats, the stages of implementation of the proposed analysis were established. The next step (after choosing the content creation formats) was to define an aggregated set of keywords associated with the thematic area / health and safety standards. The basic solution was used arbitrarily here, which literally referred to the indicated subject pointing to the phrase "health and safety at work". On this basis, the grouped derivatives were

generated. For this purpose, the web analytics tool was used to define auxiliary phrases that represent a broad spectrum of information associated with health and safety issues. It was assumed that the query of key words correlated with contents presenting the domain sphere is important. Proper identification and indication of the dependence degree with content will allow to define the effectiveness measures. At this stage, the elementary web analytics solutions of Google Planner and Google 
trends were used. The first of these is a popular Google Keyword Planner (Google's Keyword Planner for keyword exploration). It is used to develop SEO strategies, AdWords campaigns or content marketing planning. Due to the available functionality and a large integration with Google algorithms, they can be considered as a key phrase analysis tool. Within its framework, relevant metrics are declared indicating the degree of user involvement (eg monthly average number of searches for the phrase indicated in the month). Among the phrases generated by the planner there were selected those that clearly indicated the area of analysis. On the basis of the proposed words a representative group, of those that potentially can define thematic groups associated with different content formats, was created. In this case, the content creation formats defined in chapter 2 of this publication were considered. An additional element strengthening the conducted selection was the use of the Google Trends tool. Using its functionality, the popularity of selected phrases has been established over a given time horizon. For the needs of the research, it was recognized that the exact timeframe (dates) is not important, but its range (observation carried out over one year) and the definition of the region (in this case Poland). The indicated phrases have been introduced into the Buzzsumo and Brand24 systems. A tool for monitoring users' involvement in the network and the popularity of defined thematic areas (described by keywords).

As part of the considerations, the factors determining the effectiveness of the formats impact on the content creation were determined, indicating the selected indicators used as part of marketing strategies. The selection criterion was also dictated by the available functionality of the analytical tools used and the presence of adequate indicators. Due to the large number of metrics used, it was decided to use those that are correlated with the emotions presentation and user involvement (here the rates of activity in social networks and sentiments were used). Activities were represented as likes, comments and sharing materials in social media. The share percentage of all recorded activities with the appropriate division per content type is included. The nature of the observation did not exclude the possibility that the activities could simultaneously affect different formats of content. The analysis of the generated results allowed to define the following ranking of content formats: articles (74\%) in relation to which a high degree of emotional involvement was expressed in the number of sentiments. In addition, there was a clear quantitative dichotomy between positive and negative sentiments. This fact testified to the induction of strong emotions, which can also be interpreted as the involvement of network users. Graphical contents were located on the second position (infographics 67\%). Synthetic graphic message containing quantitative information that evokes positive impressions. Then there were video materials (56\%), e-books (46\%), white pages (44\%).

\section{CONCLUSIONS}

A large amount of varied information published on the web, openness of the virtual environment, dynamics, all these factors determine the necessity of introducing more and more effective methods of communication. Processes resulting from the nature of perception transformation, purchasing preferences, user activity, technological evolution in search engine algorithms determine the necessity of introducing changes in marketing strategies and in the manner of adapting formats used in communication processes with network users. Specialist thematic areas can be effectively popularized on the web based on properly selected content formats. There is no 
explicitly defined method of selection in this case, this process can be referred to as a multi-criteria decision. An important element is defining the target group to which the message is directed and associating the appropriate media with it. On the basis of the subject analysis and empirical research, one can point to the effectiveness of the web analytics tools. These solutions can be an effective support in the decision-making process related to the determination of relevant content formats.

\section{REFERENCES}

Ad blocking in the Internet. Report 2017. OnAudience.com https://www.onaudience.com/files/adblock_report.pdf (14.11.2018).

B2B Content Marketing 2018 Benchmarks, Budgets, and Trends-North America. MarketingProfs https://contentmarketinginstitute.com/wp-content/uploads/2017/09/ 2018-b2b-research-final.pdf (20.11.2018).

DeMers J., 2018. How Valuable Are Case Studies For Content Marketing? https://www.forbes.com/sites/jaysondemers/2018/01/15/how-valuable-are-casestudies-for-content-marketing/\#e88475d6d74e (24.11.2018).

Benway, J.P., Lane, D.M., 1998. Banner Blindness: Web Searchers Often Miss "Obvious". http://www.ruf.rice.edu/ lane/papers/banner_blindness.pdf (20.11.2018)

Campbell, C., Marks, L.J., 2015. Good native advertising isn't a secret. Business Horizons, 58(6), 599-606.

Conner, C., 2017. The Data Is In: Infographics Are Growing And Thriving In 2017 (And Beyond). https://www.forbes.com/sites/cherylsnappconner/2017/10/19/thedata-is-in-infographics-are-growing-and-thriving-in-2017-andbeyond/\#61174780137c. (10.11.2018).

Fessenden, T., 2018. Scrolling and Attention, https://www.nngroup.com/articles/ scrolling-and-attention/ (02.11.2018).

Gajoch-Bielecka, R., Sala, P., 2018. Email marketing w liczbach 2018. Raport Freshmail.

Hanshaw, R. Trust is the New Black: The Importance of Experts in Content Marketing. https://www.relevance.com/trust-is-the-new-black-the-importance-of-experts-incontent-marketing/ (24.11.2018).

IAB Polska/PwC AdEx: Reklama cyfrowa wciąż rośnie dwucyfrowo 2018. https://iab.org.pl/aktualnosci/iab-polskapwc-adex-reklama-cyfrowa-wciaz-rosniedwucyfrowo/ (21.11.2018).

Interactions Europe, IRCenter (2015). Reklama natywna, http://media.wix.com/ugd/ 56a698_0aa467295e9d414dae593c94f1fffce4.pdf (24.11.2018).

Kotler, P.T, Armstrong, G., 2018. Principles of Marketing. Pearson.

Lowell, D., 2017. Native Advertising. Kogan Page.

Microsoft Attention Spans Research Report 2015. Attention spans. Consumer Insights, Microsoft Canada. https://pl.scribd.com/document/265348695/MicrosoftAttention-Spans-Research-Report (10.11.2018)

Mochd Amin, M.N., Wan Nur Khalisah, S., Anith Liyana, A.N., Hoo, F.J., Shaffe, M.D., Nik Narimach, N.A., Mochd Fauzi, H., 2014. The Use of Infographics as a Tool for Facilitating Learning. Springer Singapore, (E:) Oskar Hasdinor Hassan https://www.researchgate.net/publication/284180153_The_Use_of_Infographics_a s_a_Tool_for_Facilitating_Learning 
Pagendarm, M., Schaumburg, H., 2001. Why Are Users Banner-Blind? The Impact of Navigation Style on the Perception of Web Banners. https://journals.tdl.org/jodi/index.php/jodi/article/view/36/38 (20.11.2018)

Raport Strategiczny Internet 2018. IAB Polska, PWC. https://iab.org.pl/wpcontent/uploads/2018/06/HBRP-raport-IAB-04-18.pdf (10.11.2018).

Reklama w internecie 2017 Raport. Wydawca interaktywnie.com

Sharon Hurley Hall, 2018. Video Marketing Statistics: What You Must Know for 2019. https://optinmonster.com/video-marketing-statistics-what-you-must-know/ (15.11.2018).

Shiratuddin, N., Landoni, M., Gibb, F., Shahizan, H., 2003. E-Book Technology and Its Potential Applications in Distance Education. Journal of Digital Information, 3(4) E-education: Design and Evaluation https://journals.tdl.org/jodi/index.php/jodi/ article/view/90/89

Sokołowski, A., Wrzalik, A., 2016. Świadomość znaczenia content marketingu w małych i średnich przedsiębiorstwach. [w:] Kulej-Dudek E., Kobis P., (red.) Rozwój $i$ doskonalenie funkcjonowania organizacji. Przedsiębiorstwa $w$ erze nowych technologii, działań innowacyjnych i społecznie odpowiedzialnych, Wydawnictwo Politechniki Częstochowskiej, s. 33-44.

Sokołowski, A., Wrzalik, A., 2017. Content marketing jako narzędzie wzmacniające świadomość z obszarów ergonomii stanowisk pracy. [w:] Selejdak J., KlimeckaTatar D., (red.) Techniczne i materialne aspekty bezpieczeństwa. Oficyna Wydawnicza Stowarzyszenia Menedżerów Jakości i Produkcji, Częstochowa, s. 212-223.

Stricchiola, J., Spencer, S., Enge, E., 2016. SEO czyli sztuka optymalizacji witryn dla wyszukiwarek. Wydawnictwo Helion. Gliwice.

Target Your Customers With These Top 10 High-Performing Types of Content Marketing 2018. https://www.lyfemarketing.com/blog/types-of-content-marketing/ (25.11.2018).

Video Ad Spend Study 2018. Digital Content NewFronts. IAB. https://www.iab.com/wp-

content/uploads/2018/04/2018_IAB_NewFronts_Video_Ad_Spend_Report.pdf 